\title{
Studies on Effect of Pre Harvest Treatments for Extending the Post-Harvest Life of Mango cv. Kesar
}

\author{
R. Rajya Lakshmi* and Sravanthi Guntupalli
}

Mango Research Station, Dr. Y. S. R. Horticultural University, Nuzvid - 521201, Krishna

District, (A.P.), India

*Corresponding author

\begin{tabular}{|l|}
\hline Ke y w o r d s \\
$\begin{array}{l}\text { Mango, boron, calcium } \\
\text { chloride, calcium nitrate, } \\
\text { potassium sulphate, shelf } \\
\text { life, quality, Days after } \\
\text { harvest (DAH) }\end{array}$ \\
\hline Article Info \\
$\begin{array}{l}\text { Accepted: } \\
\text { 17 May } 2018 \\
\text { Available Online: } \\
\text { 10 June } 2018\end{array}$ \\
\hline
\end{tabular}

\section{Introduction}

The mango (Mangifera indica L) is a juicy stone fruit belonging to the family Anacardiaceae and is an important fruit crop of India, as well as tropical and sub-tropical countries of the world. Mango is a national fruit of India. Besides, its excellent flavour, delicious taste, delicate fragrance and attractive colour, it is known as 'King of fruits'. It is considered to be a good source of $B$-Carotene and vitamin-A, vitamin-B complex, vitamin-C, nutritive minerals,
Mango (Mangifera indica L.) is one of the most luscious fruit of world, which occupies a prime position in the international fruit processing industry of the world. It is one of the most choicest and popular fruit among the people and designated as the 'king of fruits' (Sawke et al., 15). 7 years old mango cv. Kesar garden planted at a spacing of $7.5 \mathrm{~m} \times 7.5$ $\mathrm{m}$ was selected for the experiment. Spraying was carried out once with Taiwan sprayer at 30 days before harvest of fruits. Initial fruit weight $(\mathrm{g})$, fruit weight at 5, 10 and 15 days after harvest (DAH) was found to be non-significant among various treatments. Physiological loss of weight was significantly low in $2 \% \mathrm{~K}_{2} \mathrm{SO}_{4}$ at 5 (3.97\%), 10 (11.11\%) and $15(16.15 \%)$ DAH. $4 \% \mathrm{CaCl}_{2} \cdot 6 \mathrm{H}_{2} \mathrm{O}$ spray recorded lowest anthracnose infestation of $.87 \%$ at $10 \mathrm{DAH}, 2 \% \mathrm{CaCl}_{2} \cdot 6 \mathrm{H}_{2} \mathrm{O}$ and $2 \% \mathrm{~K}_{2} \mathrm{SO}_{4}$ sprays recorded lowest anthracnose infestation of $10.08 \%$ at $15 \mathrm{DAH}$ and $2 \% \mathrm{CaCl}_{2} \cdot 6 \mathrm{H}_{2} \mathrm{O}$ recorded lowest anthracnose infestation of $10.23 \%$ at $20 \mathrm{DAH}$. In terms of qualitative characters, significantly highest total soluble sugars $\left({ }^{\circ} \mathrm{B}\right)$ of 21.27 , total sugars percentage of 15.32 , reducing sugars percentage of 3.96 and non-reducing sugars percentage of 11.36 was recorded in $2 \%$ $\mathrm{K}_{2} \mathrm{SO}_{4}$ spray. Significantly low titrable acidity percentage of $0.25 \%$ and significantly high ascorbic acid content of $35.55 \mathrm{mg} / 100 \mathrm{~g}$ was recorded in $2 \% \mathrm{~K}_{2} \mathrm{SO}_{4}$ spray. 
its excellent quality and pleasant flavour. It is one of the leading commercial mango cultivar of India. It is usually preferred for indigenous market but now a days getting place in export market also. It is high yielder, regular bearer, having good consumer acceptance because of its attractive shape, size, colour of pulp and good keeping quality (Mane et al., 2016). So the present study was taken up to study the effect of certain pre harvest treatments on extending the post-harvest life of mango cv. Kesar under Nuzvid conditions.

\section{Materials and Methods}

The present experiment was conducted at Mango Research Station, Nuzvid, Andhra Pradesh for three years on a commercial mango cv Kesar. The selected trees were uniform in size and of 7 years age.

The experiment involved pre-harvest spray of different chemicals which includes i.e., $2 \%$ $\mathrm{CaCl}_{2} \cdot 6 \mathrm{H}_{2} \mathrm{O}, 4 \% \mathrm{CaCl}_{2} \cdot 6 \mathrm{H}_{2} \mathrm{O}, 2 \% \mathrm{Ca}\left(\mathrm{NO}_{3}\right)_{2}$, $4 \% \mathrm{Ca}\left(\mathrm{NO}_{3}\right)_{2}, 1 \% \quad \mathrm{~K}_{2} \mathrm{SO}_{4}, 2 \% \quad \mathrm{~K}_{2} \mathrm{SO}_{4}, 2 \%$ Borax and 3\% Borax which were applied as foliar spray. Spraying was carried out once with Taiwan sprayer at 30 days before harvest of fruits. Recommended package of practices schedule for mango has been followed. Data to be collected include initial fruit weight (g), weight $(\mathrm{g})$ of fruit at $5 \mathrm{DAH}$, weight of fruit (g) at $10 \mathrm{DAH}$, weight of fruit (g) at $15 \mathrm{DAH}$, physiological loss of weight $(\%)(5,10,15$ DAH), anthracnose infestation (\%) 10, 15 and 20 DAH, TSS ( ${ }^{\circ}$ Brix), titrable acidity (\%), total sugars $(\%)$, reducing sugars $(\%)$, nonreducing sugars (\%) and ascorbic acid $(\mathrm{mg} / 100 \mathrm{~g})$. Pooled statistical analysis was carried out using ANOVA.

\section{Results and Discussion}

Pooled data analysis from table 1 shows that maximum initial fruit weight was $227.78 \mathrm{~g}$ in $3 \%$ borax spray treatment and minimum initial fruit weight of $209.54 \mathrm{~g}$ was recorded in $2 \%$ $\mathrm{Ca}\left(\mathrm{NO}_{3}\right)_{2}$ treatment and the result was in coincidence with the findings of Dutta (2004) who identified appreciable improvement in fruit weight by borax application in mango cv. Himsagar. The increase in fruit weight with the sprays of borax was might be due to the involvement in hormonal metabolism, increased cell division and expansion of cell. Boron is also known to stimulate rapid mobilization of water and sugar in the fruit (Chauhan et al., 2014). Boron facilitated sugar transport within the plant and it was also reported that borate react with sugar to form a sugar-borate complex (Gauch and Dugger, 1953).

Maximum initial fruit weight at $5 \mathrm{DAH}$ was $216.38 \mathrm{~g}$ in $2 \% \mathrm{~K}_{2} \mathrm{SO}_{4}$ treatment and minimum initial fruit weight of $185.98 \mathrm{~g}$ was recorded in control. Maximum initial fruit weight at 10 DAH was $200.35 \mathrm{~g}$ in $2 \% \mathrm{~K}_{2} \mathrm{SO}_{4}$ treatment and minimum initial fruit weight of $172.69 \mathrm{~g}$ was recorded in control. Maximum initial fruit weight at $15 \mathrm{DAH}$ was $188.75 \mathrm{~g}$ in $2 \% \mathrm{~K}_{2} \mathrm{SO}_{4}$ treatment and minimum initial fruit weight of $161.96 \mathrm{~g}$ was recorded in control similarly Jakhar and Pathak (2014) observed that the spray of $2 \% \mathrm{CaCl}_{2}$ and $1 \% \mathrm{~K}_{2} \mathrm{SO}_{4}$ combined with bagging was found superior to increase the quality of fruits in respect of fruit weight, TSS, ascorbic acid, sugars, $\beta$-carotene content and TSS: acid ratio and decrease the total acidity with minimum black spotted fruits per cent and highest organoleptic quality among all treatments in both the seasons.

Minimum physiological loss of weight (PLW $\%$ ) percentage of 3.97, 11.11 and 16.15 was recorded in $2 \% \mathrm{~K}_{2} \mathrm{SO}_{4}$ treatment at 5, 10 and 15 DAH similarly Dutta et al., 2011 observed that mango trees receiving foliar spray of $\mathrm{K}_{2} \mathrm{SO}_{4}$ (1\% concentration) had a significant reduction in PLW and recorded a maximum (8 days) shelf life at ambient room temperature as compared to the other treatments. 
Table.1 Effect of pre harvest treatments for extending the post-harvest life of mango cv. Kesar 2012-15

\begin{tabular}{|c|c|c|c|c|c|c|c|c|c|c|}
\hline Treatment & $\begin{array}{l}\text { Initial } \\
\text { Fruit Wt } \\
\text { (g) }\end{array}$ & $\begin{array}{l}\text { Fruit } \\
\text { Wt } 5 \\
\text { DAH } \\
\text { (g) }\end{array}$ & $\begin{array}{l}\text { Fruit } \\
\text { Wt } 10 \\
\text { DAH } \\
\text { (g) }\end{array}$ & $\begin{array}{l}\text { Fruit Wt } \\
15 \text { DAH } \\
\text { (g) }\end{array}$ & $\begin{array}{c}\text { PLW (\%) } \\
5 \text { DAH }\end{array}$ & $\begin{array}{c}\text { PLW } \\
(\%) \\
10 \mathrm{DAH}\end{array}$ & $\begin{array}{c}\text { PLW } \\
(\%) \\
15 \mathrm{DAH}\end{array}$ & $\begin{array}{c}\text { Anthracnose } \\
\text { Infestation } \\
(\%) \\
10 \text { DAH }\end{array}$ & $\begin{array}{c}\text { Anthracnose } \\
\text { Infestation } \\
(\%) \\
\text { 15 DAH }\end{array}$ & $\begin{array}{c}\text { Anthracnose } \\
\text { Infestation } \\
(\%) \\
20 \text { DAH }\end{array}$ \\
\hline $2 \% \mathrm{CaCl}_{2} \cdot 6 \mathrm{H}_{2} \mathrm{O}$ & 214.87 & 201.83 & 188.91 & 174.28 & 6.05 & 12.07 & 18.90 & 9.99 & 10.08 & 10.23 \\
\hline $4 \% \mathrm{CaCl}_{2} \cdot 6 \mathrm{H}_{2} \mathrm{O}$ & 220.53 & 207.66 & 195.13 & 180.44 & 5.90 & 11.61 & 18.28 & 9.87 & 10.15 & 10.34 \\
\hline $2 \% \mathrm{Ca}\left(\mathrm{NO}_{3}\right)_{2}$ & 209.54 & 189.72 & 176.57 & 164.72 & 9.49 & 15.68 & 21.42 & 10.29 & 10.68 & 10.80 \\
\hline $4 \% \mathrm{Ca}\left(\mathrm{NO}_{3}\right)_{2}$ & 215.03 & 192.60 & 178.94 & 164.52 & 10.48 & 16.87 & 23.45 & 10.28 & 10.44 & 10.56 \\
\hline $1 \% \mathrm{~K}_{2} \mathrm{SO}_{4}$ & 217.21 & 207.36 & 192.71 & 181.58 & 4.58 & 11.36 & 16.34 & 10.12 & 10.39 & 10.53 \\
\hline $2 \% \mathrm{~K}_{2} \mathrm{SO}_{4}$ & 225.32 & 216.38 & 200.35 & 188.75 & 3.97 & 11.11 & 16.15 & 9.94 & 10.08 & 10.32 \\
\hline $2 \%$ Borax & 221.94 & 204.23 & 191.27 & 178.17 & 7.99 & 13.83 & 19.76 & 10.46 & 10.60 & 10.93 \\
\hline 3\% Borax & 227.78 & 207.54 & 184.40 & 183.23 & 8.95 & 14.70 & 20.54 & 10.79 & 10.86 & 11.05 \\
\hline Control & 216.89 & 185.98 & 172.69 & 161.96 & 14.45 & 20.61 & 25.53 & 11.07 & 11.25 & 11.41 \\
\hline SEM \pm & 3.52 & 3.87 & 3.55 & 11.35 & 0.15 & 0.09 & 0.13 & 0.06 & 0.04 & 0.05 \\
\hline CD & NS & NS & NS & NS & 0.44 & 0.26 & 0.39 & 0.17 & 0.13 & 0.14 \\
\hline CV (\%) & 4.83 & 5.77 & 5.70 & 20.20 & 5.50 & 1.81 & 1.94 & 1.63 & 1.28 & 1.27 \\
\hline
\end{tabular}

Table.2 Effect of pre harvest treatments for extending the post-harvest life of mango cv. Kesar 2012-15

\begin{tabular}{|c|c|c|c|c|c|c|}
\hline Treatment & $\begin{array}{l}\text { TSS } \\
\left({ }^{0} \mathbf{B}\right)\end{array}$ & $\begin{array}{c}\text { Total Sugars } \\
(\%)\end{array}$ & $\begin{array}{c}\text { Reducing Sugars } \\
(\%)\end{array}$ & $\begin{array}{c}\text { Non Reducing Sugars } \\
(\%)\end{array}$ & $\begin{array}{l}\text { Titrable Acidity } \\
(\%)\end{array}$ & $\begin{array}{l}\text { Ascorbic Acid } \\
\text { (mg / 100 g) }\end{array}$ \\
\hline $2 \% \mathrm{CaCl}_{2} \cdot 6 \mathrm{H}_{2} \mathrm{O}$ & 19.50 & 13.47 & 3.11 & 10.36 & 0.29 & 27.22 \\
\hline $4 \% \mathrm{CaCl}_{2} \cdot 6 \mathrm{H}_{2} \mathrm{O}$ & 20.35 & 13.74 & 3.45 & 10.29 & 0.26 & 24.89 \\
\hline $2 \% \mathrm{Ca}\left(\mathrm{NO}_{3}\right)_{2}$ & 19.13 & 12.73 & 2.55 & 10.17 & 0.36 & 22.22 \\
\hline $4 \% \mathrm{Ca}\left(\mathrm{NO}_{3}\right)_{2}$ & 18.13 & 13.60 & 3.26 & 10.34 & 0.35 & 23.89 \\
\hline $1 \% \mathrm{~K}_{2} \mathrm{SO}_{4}$ & 20.52 & 14.81 & 3.75 & 11.05 & 0.26 & 33.33 \\
\hline $2 \% \mathrm{~K}_{2} \mathrm{SO}_{4}$ & 21.27 & 15.32 & 3.96 & 11.36 & 0.25 & 35.55 \\
\hline $2 \%$ Borax & 19.73 & 13.49 & 3.12 & 10.37 & 0.29 & 28.33 \\
\hline 3\% Borax & 18.93 & 12.40 & 2.41 & 9.98 & 0.38 & 23.33 \\
\hline Control & 18.49 & 11.08 & 2.16 & 8.91 & 0.42 & 20.55 \\
\hline SEm \pm & 0.10 & 0.10 & 0.03 & 0.10 & 0.00 & 1.25 \\
\hline CD & 0.29 & 0.31 & 0.08 & 0.29 & 0.01 & 3.76 \\
\hline CV (\%) & 1.47 & 2.31 & 2.71 & 2.82 & 3.77 & 14.14 \\
\hline
\end{tabular}


This might be due to the fact that $\mathrm{K}_{2} \mathrm{SO}_{4}$ contains considerably more $\mathrm{SO}_{4}-\mathrm{S}$ than the other sources. This study suggests the added advantage of using $\mathrm{K}_{2} \mathrm{SO}_{4}$ as a source of $\mathrm{K}$ to improve fruit quality and shelf life of mango. Maximum PLW percentage of 14.45, 20.61 and 25.53 was recorded in control at 5, 10, 15 DAH respectively and similar findings were recorded by Jakhar and Pathak (2016) in mango cv. Amrapali pre-harvest treatment of $2 \% \quad \mathrm{CaCl}_{2}+1 \% \quad \mathrm{~K}_{2} \mathrm{SO}_{4}+$ bagging was found superior to improve the quality of fruits in respect of highest fruits weight, firmness, TSS, ascorbic acid, total sugars, and $\beta$ carotene content with minimum black spotted fruits per cent and maintained it throughout the storage period upto 18 days. Fruits treated with $2 \% \mathrm{CaCl}_{2}+1 \% \mathrm{~K}_{2} \mathrm{SO}_{4}+$ bagging showed shelf life up to 12 days with lowest weight loss and highest organoleptic quality as against 6 days of untreated fruits (control).

At 10 DAH minimum anthracnose infestation percentage of 9.87 was recorded in $4 \%$ $\mathrm{CaCl}_{2} \cdot 6 \mathrm{H}_{2} \mathrm{O}$ treatment and maximum anthracnose infestation percentage of 11.07 was recorded in control. At $15 \mathrm{DAH}$ minimum anthracnose infestation percentage of 10.08 was recorded in $2 \% \mathrm{CaCl}_{2} \cdot 6 \mathrm{H}_{2} \mathrm{O}$ and $2 \% \quad \mathrm{~K}_{2} \mathrm{SO}_{4}$ treatments and maximum anthracnose infestation percentage of 11.25 was recorded in control. At $20 \mathrm{DAH}$ minimum anthracnose infestation percentage of 10.23 was recorded in $2 \% \mathrm{CaCl}_{2} \cdot 6 \mathrm{H}_{2} \mathrm{O}$ treatment and maximum anthracnose infestation percentage of 11.41 was recorded in control. The result was in correlation with Singh et al., 1993 who observed that dip in 4$6 \% \mathrm{CaCl}_{2}$ can increase the shelf life of some cultivars as $\mathrm{CaCl}_{2}$ treatment results in low ethylene production, low respiration and reduced storage decay.

Pooled data analysis from table 2 shows that maximum TSS $\left({ }^{\circ} \mathrm{B}\right)$ of 21.27 was recorded in $2 \% \mathrm{~K}_{2} \mathrm{SO}_{4}$ treatment and minimum TSS $\left({ }^{\circ} \mathrm{B}\right)$ of 18.13 was recorded in $4 \% \mathrm{Ca}\left(\mathrm{NO}_{3}\right)_{2}$ treatment. Maximum total sugars (\%) of 15.32 was recorded in $2 \% \mathrm{~K}_{2} \mathrm{SO}_{4}$ treatment and minimum total sugars (\%) of 11.08 was recorded in control. Maximum reducing sugars (\%) of 3.96 was recorded in $2 \% \mathrm{~K}_{2} \mathrm{SO}_{4}$ treatment and minimum reducing sugars (\%) of 2.16 was recorded in control. Maximum non reducing sugars (\%) of 11.36 was recorded in $2 \% \quad \mathrm{~K}_{2} \mathrm{SO}_{4}$ treatment and minimum non reducing sugars $(\%)$ of 8.91 was recorded in control. Minimum titrable acidity (\%) of 0.25 was recorded in $2 \%$ $\mathrm{K}_{2} \mathrm{SO}_{4}$ treatment and maximum titrable acidity (\%) of 0.42 was recorded in control. Maximum ascorbic acid (mg/100 g) of 35.55 was recorded in $2 \% \quad \mathrm{~K}_{2} \mathrm{SO}_{4}$ treatment and minimum ascorbic acid (mg/100 g) of 20.55 was recorded in control. Storage methods and post-harvest treatments to mangoes affect colour, ripening level, TSS, acidity and reduce the decay level and increase the shelf life, which in turn affect the market acceptability (Jha et al., 2010).

In terms of qualitative characters, significantly highest total soluble sugars $\left({ }^{\circ} \mathrm{B}\right)$ of 21.27, total sugars percentage of 15.32, reducing sugars percentage of 3.96 and nonreducing sugars percentage of 11.36 was recorded in $2 \% \mathrm{~K}_{2} \mathrm{SO}_{4}$ spray the result was similar to the findings of dutta et al., 2011 who observed that the application of $\mathrm{K}_{2} \mathrm{SO}_{4}$ significantly increased the total soluble solids, total sugar and $\beta$-carotene content of fruits over $\mathrm{KCl}$ and $\mathrm{KNO}_{3}$ treated trees. Higher fruit quality, especially higher sugar content can be explained by the role of $\mathrm{K}$ in carbohydrate synthesis, breakdown and translocation and synthesis of protein and neutralization of physiologically important organic acids.

Marcio A. Carneiro et al., 2017 observed higher efficiency with respect to the production per plant and yield of mango, in comparison to the fertilization with potassium 
chloride, and the dose of $174.24 \mathrm{~g}$ per plant of potassium sulfate is recommended for a fruit yield of $23.1 \mathrm{t} /$ ha under the studied conditions with fertilization of potassium sulfate. Significantly low titrable acidity percentage of $0.25 \%$ and significantly high ascorbic acid content of $35.55 \mathrm{mg} / 100 \mathrm{~g}$ was recorded in $2 \% \mathrm{~K}_{2} \mathrm{SO}_{4}$ spray the result is in coincidence with barbade and kulkarni (2012) who reported significantly maximum TSS (12.91 $\left.{ }^{\circ} \mathrm{B}\right)$, total sugars $(11.54 \%)$ and minimum acidity $(0.44 \%)$ was recorded in T4 (Mulching $+\mathrm{K}_{2} \mathrm{SO}_{4} 1 \%$ ) at harvest. Similarly at edible maturity also significant maximum TSS $\left(19.54{ }^{\circ} \mathrm{B}\right)$, total sugars $(16.52 \%)$ and minimum acidity $(0.20 \%)$ was recorded in $\mathrm{T} 4$ (Mulching $+\mathrm{K}_{2} \mathrm{SO}_{4} 1 \%$ ) in mango cv. Kesar. Similar study by Thirupathi and Ghosh (2015) concluded that Bassein Seedless had highest fruit yield and Ruby had good quality fruits of Pomegranate (Punica granatum L.) by foliar application of water soluble fertilizers $\mathrm{KNO}_{3}$ and $\mathrm{K}_{2} \mathrm{SO}_{4}$ among seven cultivars grown in laterite soils of West Bengal. In general, all the 7-cultivars responded well in respect to fruit yield, fruit size and taste (TSS/acid ratio), to foliar feeding of nutrients as compared to un-sprayed (control).

\section{References}

Barbade Shashikant S and Kulkarni 2012. Studies on effect of pre harvest spray for extending shelf life of mango $c v$. Keshar. M.Sc Ag. thesis submitted to the Mahatma Phule Krishi Vidyapeeth, Rahuri.

Chauhan, P., Singh, J.P., Indu arora and Singh R.K. 2014. Flowering, fruiting, yield and physical character of fruit of mango cv. Dashehari as influenced by preharvest foliar spray of nutrients and plant bio-regulators. Asian J Hort., 9(2): 459-462.

Dutta, P. (2004). Effect of foliar application on panicle growth, fruit retention and physicochemical characters of mango cv. Himsagar. Indian J. Hort., 61 (30): 265-266.

Dutta, P., Ahmed, B. and Kundu, S. 2011. Better Crops -South Asia, 5(1): 16-18.

Gauch, H.G. and Dugger, W.M. J. (1953). The role of boron in the translocation of sucrose. Pl. Physiol., 28: 457-466.

Jakhar and Pathak 2014. Enhancing quality of mango (Mangifera indica L.) fruits $c v$. Amrapali with pre-harvest foliar spray and fruit bagging. Annals of Agri Bio Research 19(3): 488-491.

Jakhar and Pathak 2016. Effect of Pre-harvest nutrients application and bagging on quality and shelf life of mango (Mangifera indica L.) Fruits $c v$. Amrapali. J. Agr. Sci. Tech. 18: 717729.

Jha S. N. Narsaiah K. Sharma A. D. Singh M. Bansal S. Kumar R. 2010. Quality parameters of mango and potential of non-destructive techniques for their measurement - a review. J Food Sci Technol., 47(1): 1-14.

Krishnamurthy, S. and Rao, D.V.S. (2001). Status of post-harvest management of fruits. Indian J. Hort., 58 (1-2): 152.

Mane, Shailendra R., Jadhav, Y.T. and Barkade, D.P. (2016). Effect of maturity indices, post-harvest treatments and storage temperature on shelf-life of mango $c v$. Kesar. Asian J. Hort., 11(1): 202-207.

Marcio A. Carneiro, Augusto M. N. Lima, Italo H. L. Cavalcante, Jailson C. Cunha, Marcos S. Rodrigues \& Thiago B. da S. Lessa. 2017. Soil salinity and yield of mango fertigated with potassium sources. R. Bras. Eng. Agric. Ambiental, 21(5):310-316.

Singh BP, Tandon DK, Kalra SK (1993). Changes in postharvest quality of mangoes affected by pre harvest application of calcium salts. Scientia Hort., 54: 211-219. 
Thirupathi N and Ghosh S.N. 2015. Effect of Foliar Feeding of $\mathrm{KNO}_{3}$ and $\mathrm{K}_{2} \mathrm{SO}_{4}$ on Yield and Quality of Some Pomegranate Cultivars Grown in
Laterite Soils of West Bengal. International Journal of Tropical Agriculture. 33(4): 2835-2839.

\section{How to cite this article:}

Rajya Lakshmi R. and Sravanthi Guntupalli. 2018. Studies on Effect of Pre Harvest Treatments for Extending the Post-Harvest Life of Mango cv. Kesar. Int.J.Curr.Microbiol.App.Sci. 7(06): 1527-1533. doi: https://doi.org/10.20546/ijcmas.2018.706.181 